\title{
АКАДЕМИКУ РАН
}

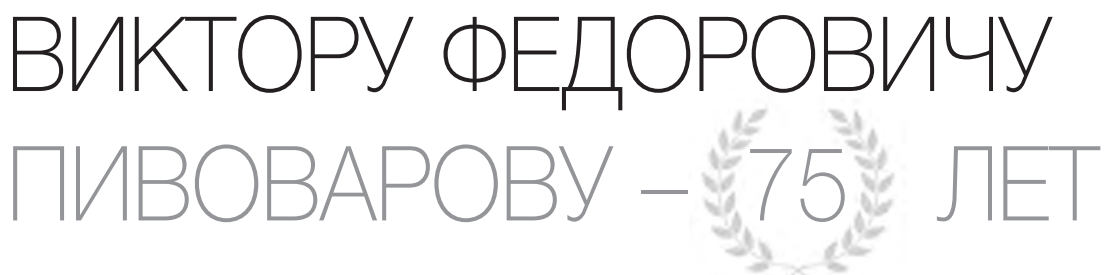

\section{5th BIRTH ANNIVERSARY OF PIVOVAROV VICTOR FEDOROVICH, ACADEMICIAN OF RUSSIAN ACADEMY OF SCIENCES}

Пышная О.Н. - доктор с.-х. наук, зам. директора по науке Гуркина Л.К. - канд. с.-Х. наук, Ученый секретарь Науменко Т.С. - С.Н.С., канд. С.-Х. наук Тареева М.М. - С.Н.С., канд. С.-Х. наук

ФГБНУ «Всероссийский НИИ селекции и семеноводства овощных культур» 143080, Россия, Московская область, Одинцовский район, пос. ВНИИССОК, ул. Селекционная, д.14 Тел. +7(495) 599- 24- 42; факс: (495) 599- 22-77 E-mail: vniissok@mail.ru

18 апреля 2017 года исполняется 75 лет со дня рождения доктору сельскохозяйственных наук, профессору, академику РАН, Заслуженному деятелю науки РФ, лауреату Государственной премии и премии Правительства РФ по науке и технике, директору ФГБНУ «Всероссийский НИИ селекции и семеноводства овощных культур» Виктору Федоровичу Пивоварову.

Вгов иктор Федорович Пивоваров родился 18 апреля 1942 года в с. Коповка Пачелмского района Пензенской области в семье служащих. Его мама - Нина Евсеевна - воспитанница детского дома, была тихой, скромной женщиной, работала учительницей начальных классов, а затем воспитательницей в детском саду. Отец - Федор Тимофеевич - по специальности электрик и радиотехник, в отличие от мамы был суров и строг. Детство Виктора Федоровича совпало с трудными военными и послевоенными годами, поэтому еще в детские годы ему вместе со старшей сестрой Галиной пришлось познать всю тяжесть лихолетья. После войны отец вернулся домой, и родители приняли решение переехать ради учебы детей в районный центр Пачелма.

После окончания в 1959 году средней школы Пивоваров поступает в Пензенский сельскохозяйственный институт на агрономический факультет. Интерес к селекции и семеноводству Виктору Федоровичу привил профессор Гуляев Г.В., будущий академик ВАСХНИЛ, работавший в то время ректором Пензенского СХИ.

Свою трудовую деятельность В.Ф. Пивоваров начал в 1964 году агрономом на производстве, затем преподавателем профессионально-технического училища в г.Беднодемьяновске Пензенской
Pyshnaya O.N.,

Gurkina L.K.,

Naumenko T.S.,

Tareeva M.M.

Federal State Budgetary Research Institution

'All-Russian Research Institute

of Vegetable Breeding and Seed Production'

143080, Russia, Moscow region, Odintsovo district, p. VNIISSOK,

Selectionnaya St, 14

E-mail: vniissok@mail.ru

On April 18 ${ }^{\text {th }}$, a doctor of agricultural sciences, professor, a member of Russian Academy of Sciences, academician, Honored Research Worker in Science and Technology, State Laureate of the Russian Federation Government Prize in Science and Technology, a director of Federal State Budgetary Research Institution 'All-Russian Research Institute of Vegetable Breeding and Seed Production', Victor Fedorovich Pivovarov celebrates his 75th birth anniversary.

области, служил в Вооруженных силах. После службы в армии работал инженером-почвоведом в Чувашском сельскохозяйственном институте.

В 1968 году Виктор Федорович поступает в аспирантуру при Грибовской овощной селекционной опытной станции. После успешной сдачи экзаменов он становится аспирантом известного ученого-селекционера по тыквенным культурам, профессора, доктора с.-Х. наук О.В. Юриной. В 1972 году, после окончания аспирантуры, В.Ф. Пивоваров успешно защитил диссертацию на соискание ученой степени кандидата с.-х. наук по разработке методических вопросов селекции огурца на групповую устойчивость к болезням.

С 1975 по 1981 год наступил особый период в творческой биографии В.Ф. Пивоварова, оставивший в его жизни незабываемый след и неизгладимые впечатления. В тропиках Республики Куба он выполняет научные исследования на организованном Минсельхозом СССР и ВАСХНИЛ экспериментальном советско-кубинском участке «Дружба», который был создан для ускорения селекционного процесса и выполнял роль естественного фитотрона для испытания и оценки на адаптивность и устойчивость к болезням многих перспективных сортоообразцов овощных культур нашей страны, а также служил полигоном для создания новых сортов, приспособленных для выращивания в 

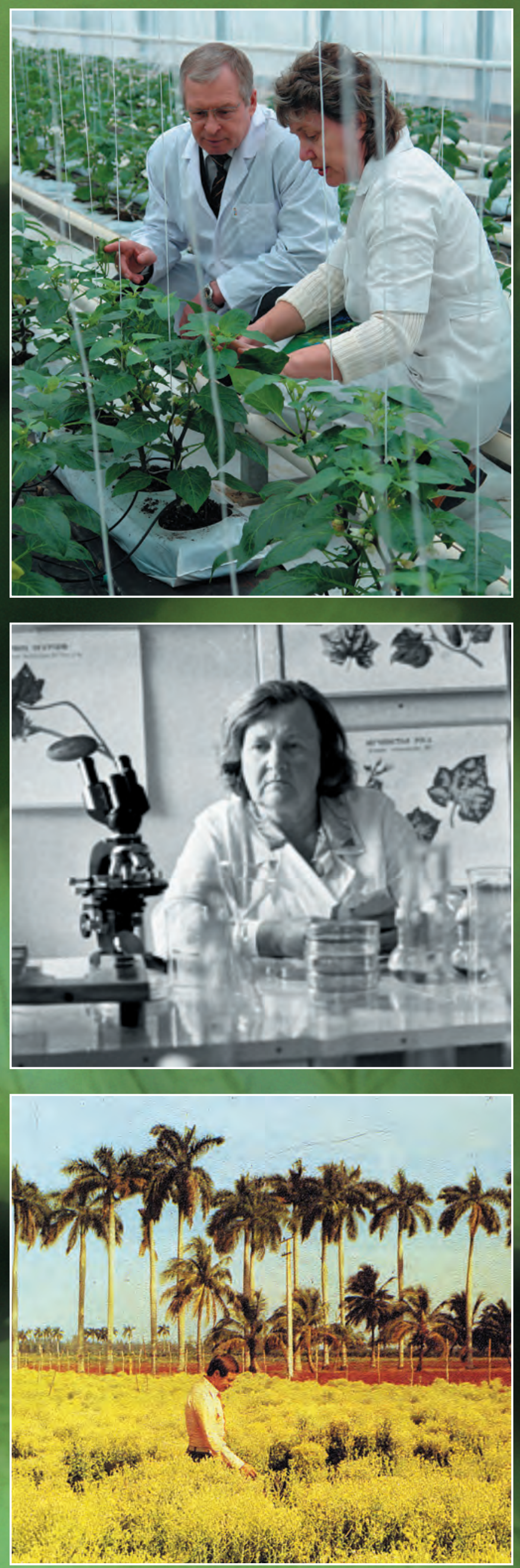

условиях СССР и Р. Куба. За этот период для условий Р. Куба было создано 8 сортов овощных культур (огурец, томат, перец, горох овощной, фасоль, укроп и др.), превосходящих коммерческие по урожайности, устойчивости к болезням, адаптивности, а также выделено более 30 новых ценных генисточников, которые получили распространение и в странах Латинской Америки (Мексика, Аргентина). Интродуцированы на Кубу из СССР новые, не выращиваемые ранее растения, организованы и проведены несколько международных совещаний, опубликованы результаты совместных исследований и подготовлены высококвалифицированные кадры для Р.Куба. Научная работа советских специалистов на Кубе под руководством В.Ф. Пивоварова получила высокую оценку Министерства сельского хозяйства и Академии Наук Республики Куба и лично Фиделя Кастро.

После возвращения с Кубы В.Ф. Пивоваров приходит работать в лабораторию экологии ВНИИССОК, которую возглавляет доктор c.-х. наук Т.А. Зимина. В лаборатории продолжаются исследования по испытанию овощных культур в различных почвенно-климатических зонах СССР с целью ускорения селекции и создания экологически стабильных, адаптивных сортов и гибридов, устойчивых к болезням.

Результаты научных исследований по ускорению селекционного процесса, полученные в условиях тропиков, а позднее и в других климатических зонах различных регионов СССР (Узбекистан Термез, Азербайджан - Ленкорань, центральная зона - Москва) и их успешная практическая реализация в виде сортов и гибридов овощных культур, позволили В.Ф. Пивоварову в 1986 году успешно защитить диссертацию на соискание ученой степени доктора сельскохозяйственных наук.

С 1983 года В.Ф. Пивоваров совмещает работу заместителя директора по науке и заведующего отделом экологии ВНИИССОК. В 1982-1989 годах под его руководством, научный коллектив отдела экологии совместно с ведущими специалистами Госкомиссии по сортоиспытанию с.-х. растений проводит серию исследований по оценке исходного материала и разработке новых селекционных технологий на устойчивость к биотическим и абиотическим стрессорам для отбора высокопродуктивных и экологически стабильных сортов, определяет возможности использования стабилизирующих фонов для размещения зон товарного семеноводства.

Научные разработки В.Ф. Пивоварова не остались незамеченными, и в 1990 году он избирается профессором по специальности «селекция и семеноводство». Продолжая активно заниматься научной и административной деятельностью, он получал максимум поддержки в реализации своих идей и планов со стороны директора ВНИИССОК С.И. Сычева (1983-1992). Кто знает, как бы в дальнейшем сложилась его научная работа и творческая карьера, не будь этой поддержки и помощи? После ухода с поста директора С.И.Сычев предложил на эту должность своего заместителя, и в 1992 году В.Ф. Пивоваров назначается директором Всероссийского НИИ селекции и семеноводства овощных культур. В 1993 году он избирается членом - корреспондентом РАСХН по специальности «генетика и селекция», а в 1995 году - действительным членом (академиком) Российской академии сельскохозяйственных наук.

Научная деятельность В.Ф. Пивоварова связана с разработкой нового направления исследований по интродукции, селекции и генетике овощных культур, основанного на последовательном использовании различных эколого-географических зон, как 
естественных фитотронов, для ускорения и повышения эффективности селекционного процесса. Под руководством В.Ф. Пивоварова развивается направление исследований - использование овощей в лечебно-профилактическом питании по принципу «Овощи - пища - лекарство». В рамках этих исследований успешно проводится селекционная работа на высокое содержание биологически активных соединений, в том числе на антиоксидантную активность и повышенное содержание микронутриентов. Конечным результатом этих исследований является производство продуктов фуннционального назначения, направленных на повышение иммунного статуса и увеличение продолжительности жизни человека. Именно за научные разработки в области интродукции и селекции овощных культур на повышенное содержание биологически активных веществ и антиоксидантов, имеющих важное социальное значение в решении проблем питания, здоровья нации и способствующих укреплению экономической безопасности России, коллектив ученых - овощеводов во главе с В.Ф. Пивоваровым удостоен в 2003 году звания лауреатов Государственной премии, а в 2013 году премии Правительства РФ в области науки и техники.

Многолетние исследования В.Ф. Пивоварова опубликованы в более 620 научных работах по самым актуальным проблемам отрасли селекции и семеноводства овощных культур, он является автором свыше 35 книг, монографий, учебников и методических указаний, соавтором 125 сортов и гибридов овощных культур и 17ти изобретений. Значительный интерес для селекционеров, семеноводов, преподавателей ВУЗов, аспирантов представляет ряд монографий по частной селекции овощных культур (пасленовым, тыквенным, луковым, корнеплодным, капустным, нетрадиционным и др. культурам), опубликованных В.Ф. Пивоваровым в 1992-2016 годах совместно с генетиками, селекционерами, семеноводами ВНИИССОК, ВИР им. Н.И.Вавилова и других НИУ.

Широкую популярность завоевала книга Виктора Федоровича «Овощи России", предназначенная для специалистов и овощеводов-любителей, изданная несколькими тиражами на русском и английском языках.

В настоящее время институт выпускает авторитетный теоретический журнал «Овощи России», входящий в российские (РИНЦ) и международные (Agris) базы цитирования, главным редактором которого является академик В.Ф. Пивоваров.

Научная школа экологической селекции академика В.Ф. Пивоварова имеет мировое признание. Многие отечественные и зарубежные специалисты, работающие в отрасли овощеводства его ученики. Под руководством Виктора Федоровича подготовлены 44 кандидата и 17 докторов наук в России, Украине, Азербайджане, Узбекистане, Туркмении, Республике Куба, сейчас обучается 6 аспирантов и докторантов.

Преодолевая трудности времени, институт во главе с директором В.Ф. Пивоваровым успешно справляется с научными планами Государственного задания по всем представленным в нем исследовательским направлениям. Развиваются теоретические исследования по разработке инновационных технологий и методов ускоренного создания принципиально нового, качественного исходного материала для селекции. В институте созданы богатейшие коллекции, насчитывающие десятки сотен генисточников и доноров продуктивности, скороспелости, высокого качества, устойчивости к биотическим и абиотическим стрессорам по тыквенным, пасленовым, луковым, бобовым, корнеплодным, капустным, зеленным,
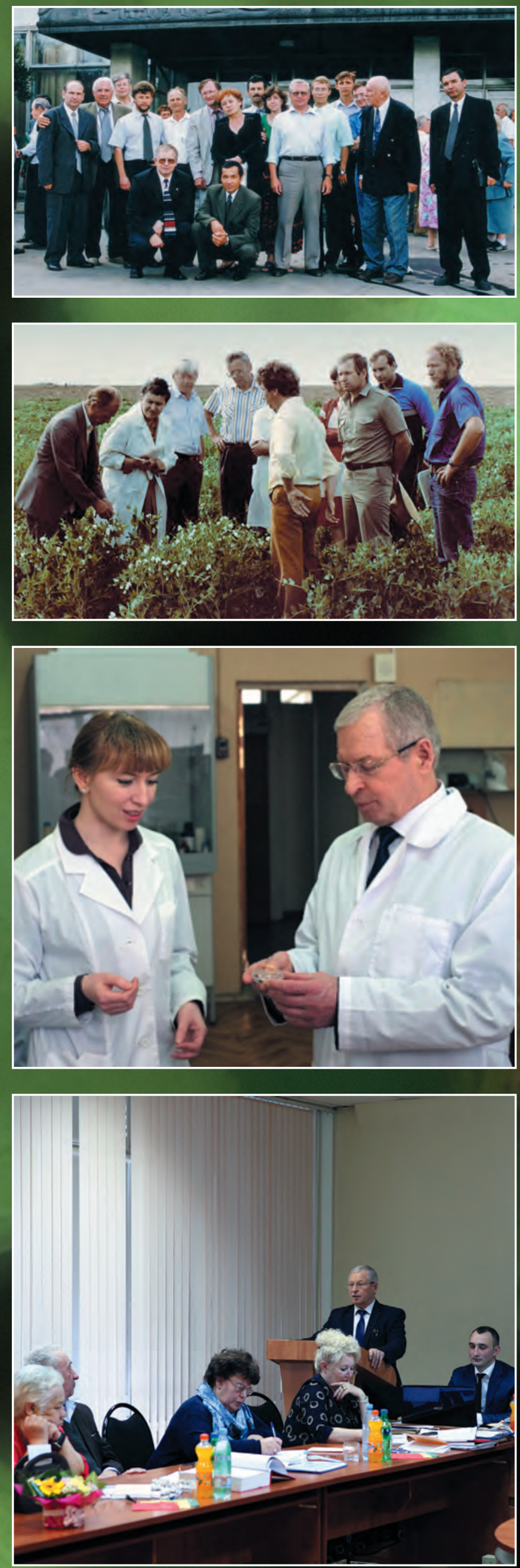
пряно-ароматическим и цветочным культурам. В последние годы развернуты фундаментальные исследования по разработке новых технологий, интенсифицирующих селекционный процесс на основе биотехнологических и молекулярных методов.

Находясь на посту директора, В.Ф. Пивоваров сохраняет лучшие традиции отечественной селекционной школы, развивая и усиливая исследования не только по фундаментальным, но и по приоритетным прикладным разработкам в области селекции и семеноводства более чем 118-ти овощных, пряно-ароматических, нетрадиционных и цветочных культур. Практическая отдача такой работы велика. Ежегодно в институте создается 20-25 сортов и гибридов. Всего учеными - селекционерами ВНИИССОК в сотрудничестве со специалистами смежных специальностей: генетиками, биотехнологами, иммунологами и др. создано более 850 сортов и гибридов $F_{1}$ овощных, бахчевых, пряно-ароматических, цветочных и новых нетрадиционных культур, из которых 587 сортов и гибридов внесены в Госреестр РФ на 2017 год, причем, большая часть из них создана институтом за последние 10-15 лет. Развивается семеноводство, как неотьемлемая часть селекционного процесса; сотрудниками института ежегодно выращивается от 8 до 10 т оригинальных семян и 200-600 т репродукционных. Некоторые сорта селекции института занимают до 50\% посевов овощных культур в Российской Федерации.

По инициативе и под руководством В.Ф. Пивоварова в институте постоянно проводятся мероприятия, на которых отмечаются юбилейные даты в истории развития института, международные конференции, симпозиумы, совещания по состоянию и перспективам развития отрасли селекции и семеноводства овощных культур, новым нетрадиционным культурам с привлечением большого количества специалистов из России, стран ближнего и дальнего зарубежья. Институт является центром подготовки и переподготовкеи специалистов по апробации овощных культур.

Овощеводческая наука стоит на пороге новых преобразований. На базе нашего института создается «ФЕДЕРАЛЬНЫЙ НАУЧНЫЙ ЦЕНТР ОВОЩЕВОДСТВА», куда войдут институты: ВНИИССОК, ВНИИО и 6 опытных станций, расположенных в различных регионах России. Надеемся, что новое преобразование позволит консолидировать усилия ученых для эффективного решения проблемы обеспечения потребности отечественного рынка семенами и посадочном материалом овощных, бахчевых культур.
Наряду с плодотворной научной деятельностью, В.Ф. Пивоваров выполняет значительную общественную работу в качестве члена совета по присуждению Премий Правительства РФ в области науки и техники; является председателем спецсовета по защите докторских и кандидатских диссертаций; председателем методической комиссии по теоретическим и методическим вопросам селекции и семеноводства овощных культур и др.

Виктор Федорович пользуется авторитетом среди ученых России, стран СНГ и дальнего зарубежья, выполняя большую научно-организационную работу. Неоднократный участник и представитель международных симпозиумов ЕУКАРПИИ по селекции овощных культур и экологии, международных сельскохозяйственных выставок во Франции, Нидерландах, Германии, Великобритании. Он хорошо знаком с овощеводством стран Латинской Америки, Европы, Индии, Китая, Японии, уделяя максимум внимания поддержке и развитию международных связей. Знание испанского языка позволяет ему активно общаться с иностранными коллегами, выступать на международных симпозиумах, конференциях с докладами.

В чем секрет научного и творческого долголетия академика Пивоварова? Это прежде всего преданность делу науки, высокий профессионализм, стратегическое видение перспектив, умение ставить цели и добиваться их достижения, научная добросовестность и принципиальность.

В жизни академик Пивоваров - многогранная творческая личность. Он весельй и компанейский человек, играет на баяне, любит слушать и петь песни, умеет интересно рассказывать забавные истории, всегда с удовольствием участвует в институтских вечерах. Любит охоту, рыбалку, где встречается со своими друзьями и эти встречи приносят ему заряд бодрости и сил.

Еще одной отличительной чертой Виктора Федоровича является его самозабвенное увлечение спортом. Всегда, в школе, институте, армии, аспирантуре, на работе - он спортсмен. До сих пор он играет в волейбол, катается на лыжах, занимается бегом.

Авторы данной статьи и весь коллектив института от всей души желают юбиляру доброго здоровья, творческого и жизненного долголетия, энергии, новых достижений в науке. Мы убеждены, что к нашим пожеланиям с радостью присоединятся коллеги и друзья Виктора Федоровича, которым когда-либо доводилось профессионально или просто по-дружески общаться.

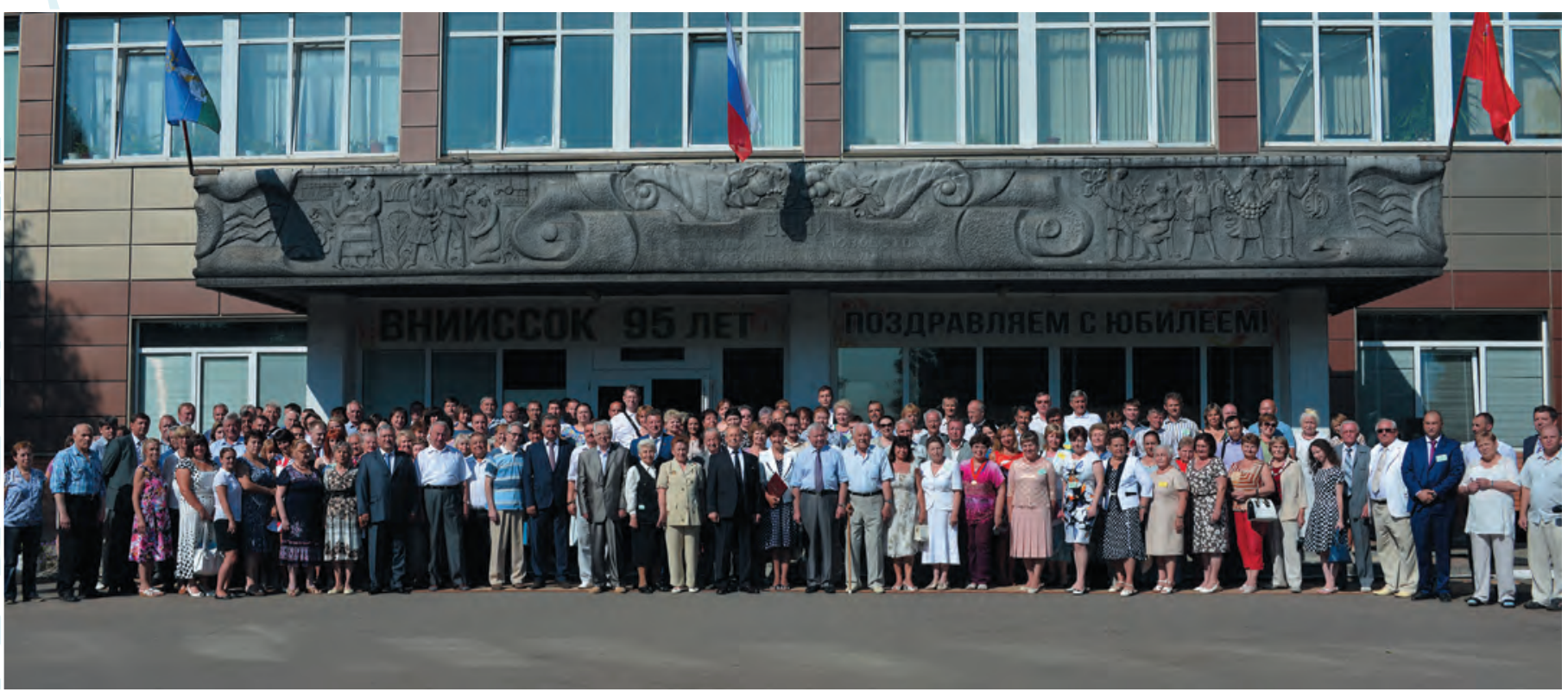

